\section{Forner-Alcaide 5 and Forner-Alcaide 13: Two New Citrus Rootstocks Released in Spain}

\author{
Juan B. Forner ${ }^{1}$, M. Angeles Forner-Giner, and Antonio Alcaide \\ Departamento de Citricultura y Otros Frutales, Instituto Valenciano de \\ Investigaciones Agrarias, Apartado Oficial, 46113 Moncada, Valencia, \\ Spain
}

Additional index words. breeding, citrus tristeza virus, Cleopatra mandarin, Poncirus trifoliata, salinity, Tylenchulus semipenetrans

The search for new citrus rootstocks with better performance than those currently used is the major aim of the citrus industry in many countries. New diseases, the spread of known diseases, and citrus culture under different environmental conditions force the demand for new rootstocks. Carrizo citrange [Citrus sinensis (L.) Osb. X Poncirus trifoliata (L.) Raf.], the most used rootstock in Spain, frequently shows iron chlorosis and salinity problems. Other less common rootstocks, such as Cleopatra mandarin (C.reshni Hort. ex Tan.), C. volkameriana Ten. \& Pasq., Swingle citrumelo (C. paradisi Macf. x P. trifoliata), and C. macrophylla Wester, do not conveniently solve the problems.

Forner-Alcaide 5 (F-A 5) and Forner-Alcaide 13 (F-A 13) are two interspecific hybrids obtained through traditional hybridization by the senior author in a program for breeding citrus rootstocks at the Instituto Valenciano de Investigaciones Agrarias (IVIA) in Moncada (Valencia), Spain. The goals of the breeding program were to obtain new rootstocks tolerant to CTV, salinity, and lime-induced chlorosis and resistant to Phytophthora sp. (Forner and Alcaide, 1993, 1994; Forner et al., 1997).

\section{Origin}

F-A 5 and F-A 13 are selections of Cleopatra mandarin $\times$ P. trifoliata 'Rubidoux' crosses completed in 1978.

Seeds from mature fruits of the cross were extracted and sowed in vitro on a Murashige and Skoog medium. In these conditions, almost all embryos grew normally. Hybrid seedlings, identified because of the trifoliolate leaves, were transplanted to pots with a substrate of

Received for publication 28 May 2002. Accepted for publication 30 Sept. 2002. We thank Emilio Carbonell for statistical advice with the breeding program, José Francisco Ballester-Olmos for providing citrus tristeza virus strains, Mariano Cambra for ELISA tests, and Manuel Talón and Manuel Agustí for critical reading of the manuscript. This work was financed by the Instituto Nacional de Investigación y Tecnología Agraria y Alimentaria (INIA) and Instituto Valenciano de Investigaciones Agraria (IVIA) grants no. 8127, SC94-037-C2, SC98-103C2, and RTA02-104.

${ }^{1}$ To whom reprint requests should be sent. E-mail address: jforner@ivia.es; fax: +34 963424001. peat and sand and grown in a greenhouse. The first flowering of the F-A 5 hybrid took place in the greenhouse during Spring 1981, and of the F-A 13 hybrid during Spring 1983.

The accession numbers assigned to F-A 5 and F-A 13 were 03015 and 030113 , respectively.

\section{Description}

Trees of F-A 5 and F-A 13 on Carrizo citrange rootstock (seed mother trees on the field, 16-years-old) are of medium size, round-topped, with profuse branching with short and thin branchlets. On these plants, thorns are conical shaped, small ( $<1 \mathrm{~cm}$ long), and abundant.

$F-A$. The leaves of the F-A 5 are trifoliolate, most of a pale green color, and deciduous. The central leaflet is 40 to $50 \mathrm{~mm}$ long and 10 to $15 \mathrm{~mm}$ wide. The lateral leaflets are 20 to 35 $\mathrm{mm}$ long and 5 to $10 \mathrm{~mm}$ wide. The petiole is 15 to $20 \mathrm{~mm}$ long with small wings. The leaflets are crenate-margined on the upper half.

The very young floral buds and filaments of stamens have a pallid pink color on the upper sunny part, but soon become white as the flower develops. Flowers have spoon-shaped white petals. The style and stigma are of the same length as the stamens. The diameter of a
Fig. 1. Fruits and seeds of 'Forner-Alcaide 5' (F-A 5). fully open flower is 2 to $3 \mathrm{~cm}$, and the anthers remain close to the stigma.

Fruit is slightly flat and mandarin-like, with a weight of about $35 \mathrm{~g}$, a diameter of 40 to 45 $\mathrm{mm}$, and a height of $35 \mathrm{~mm}$ (Fig. 1). The peel is thick with a rather rough surface. Fruit ripen in November.

The fruit contain about 20 polyembryonic whitish seeds. The number of seeds in a kilogram ranked between 8,000 to 10,000 .

$F$-A 13. Most leaves of the F-A 13 are trifoliolate and deciduous. Size and shape of its leaves are very similar to those of F-A 5. The central leaflet is 40 to $50 \mathrm{~mm}$ long and 15 to 20 $\mathrm{mm}$ wide. The lateral leaflets are 25 to $35 \mathrm{~mm}$ long and 10 to $15 \mathrm{~mm}$ wide. The petiole is 10 to $20 \mathrm{~mm}$ long with small wings. The leaflets are crenate-margined on the upper half.

The external parts of the young floral buds and filaments of the stamens also have a light pink color, but the color is more intense than in F-A 5. The pink color is distributed around the flower and remains on the lower half of the filaments when the flowers open (Fig. 2). Opened flowers have spoon-shaped white petals. The stamens are longer than the style and stigma. Fully open flowers are 25 to $30 \mathrm{~mm}$ in diameter and the stamens are curved to petals.

Fruit is rounded and mandarin-like, with a mean weight of $45 \mathrm{~g}$, a mean diameter of $48 \mathrm{~mm}$, and a mean height of $43 \mathrm{~mm}$ (Fig. 3). The peel is thick with a rough surface. Fruit ripen in November.

Fruit may have more than 30 polyembryonic and whitish seeds. One kilogram of seeds contains more than 7000 seeds.

\section{Performance}

Both selections, F-A 5 and F-A 13, are resistant to CTV, because the virus does not replicate in tissues of seedlings of both hybrids inoculated with each one of three CTV isolates: T-315 (mild), and T-344 and T-340 (moderates) (Ballester-Olmos et al., 1993; Forner et al., 1997). Tests for tolerance or susceptibility to citrus exocortis and cachexia viroids are in progress.

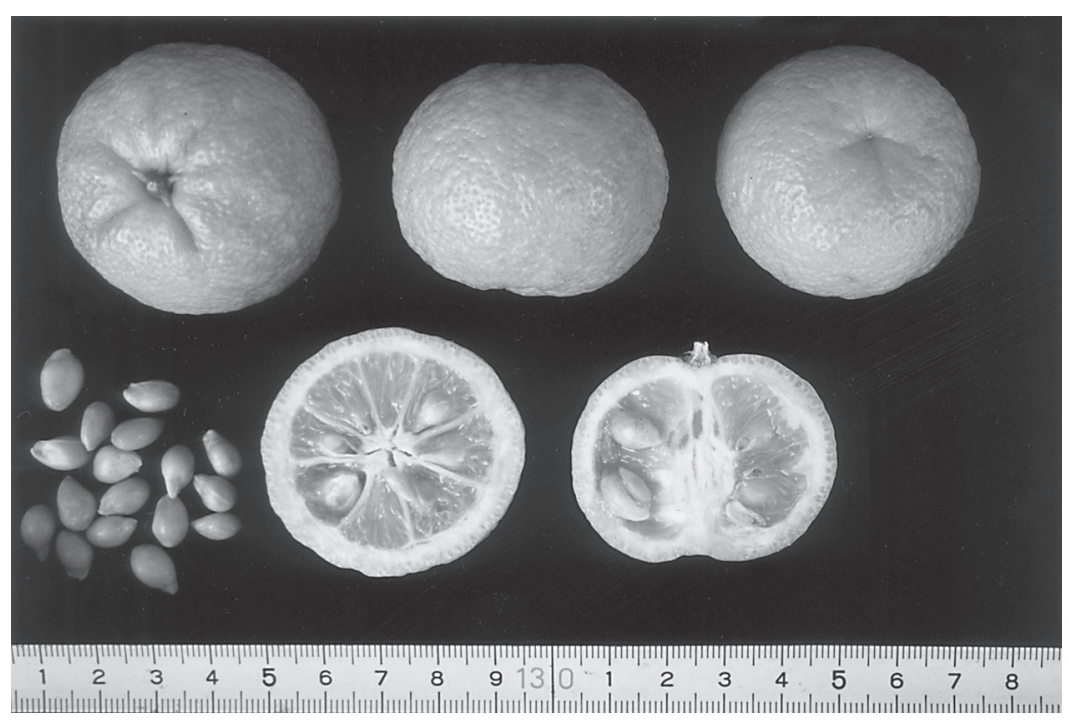




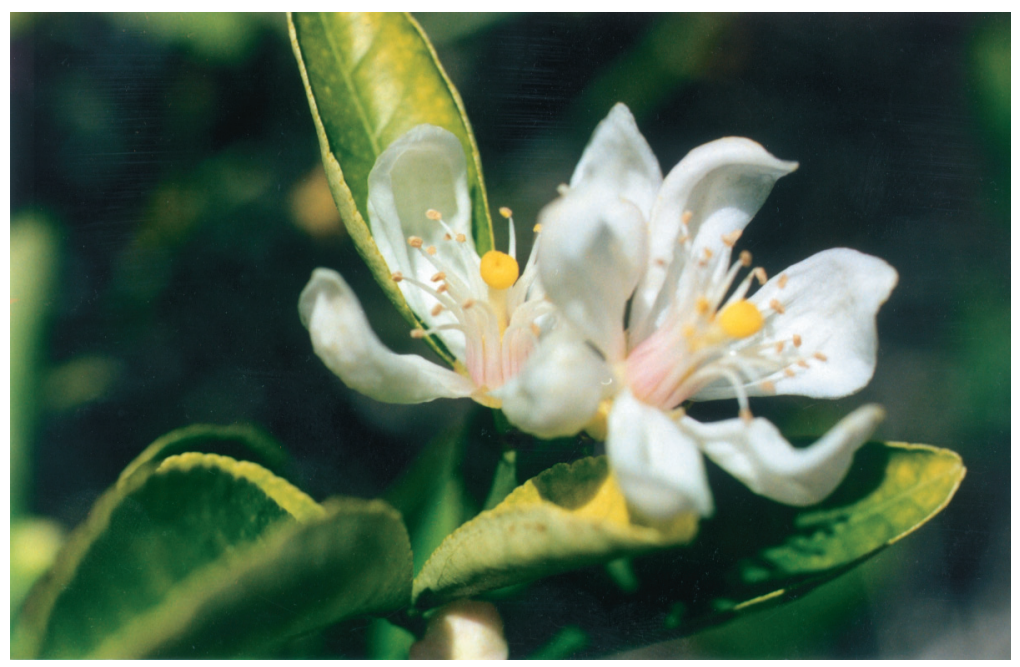

Fig. 2. Pink color on the lower half of the filaments in flowers of F-A 13.

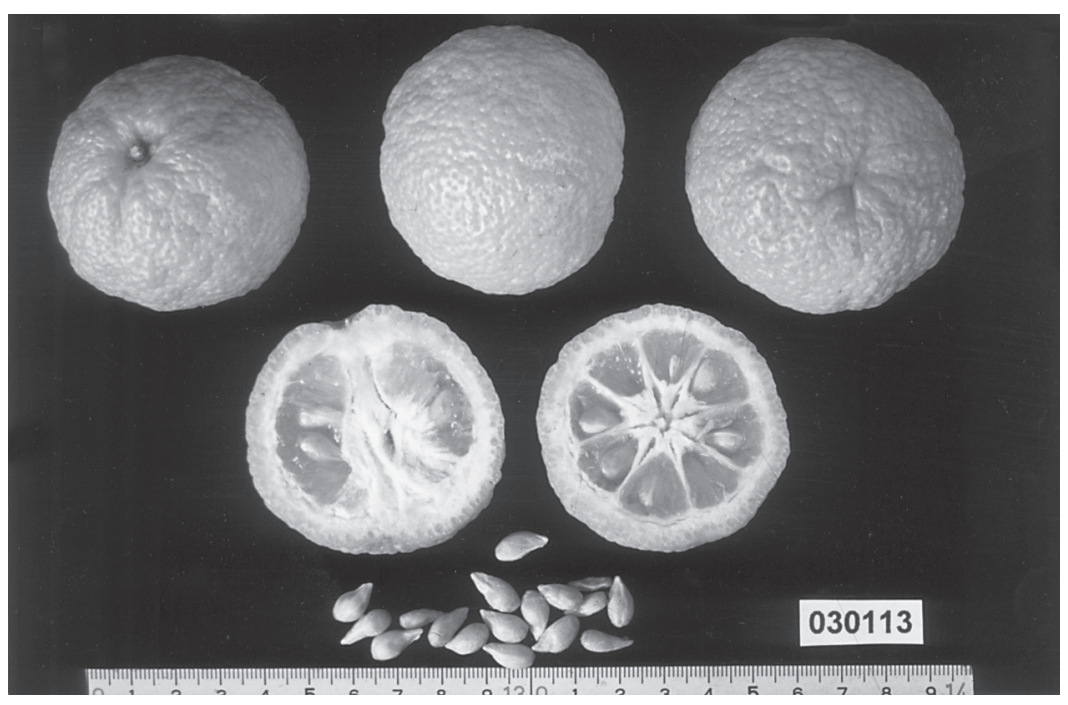

tions, tree sizes were smaller than on Carrizo citrange rootstock, and they can be classified as substandard to semidwarfing rootstocks. Similar results were obtained (Forner-Giner et al., 2003) in another experimental plot of 'Okitsu' satsuma, planted in 1990 in a similar soil, but only with F-A 5 and Carrizo citrange rootstocks. Several younger trials with orange and Clementine varieties on F-A 5, F-A 13 , Carrizo citrange, and other rootstocks have been planted in different Spanish ecologies. The first results obtained in these experimental plots agree with those described before.

The bud union is relatively smooth with all varieties grafted at present on both selections, with little overgrowth of the rootstock (Forner et al., 1997).

\section{Availability}

F-A 5 has been registered for protection in the European Union by the Instituto Valenciano de Investigaciones Agrarias (IVIA), Apartado Oficial, 46113 Moncada (Valencia), Spain, and the Instituto Nacional de Investigación y Tecnología Agraria y Alimentaria (INIA), Carretera de La Coruña km 7.5, 28040 Madrid, Spain. It has been released to the Spanish citrus nursery industry, and commercial propagation will soon begin for those who have signed a contract. No one nursery has exclusive propagation rights within the European Union.

Similar protection is being sought for F-A 13.

Small quantities of seeds of both selections are available for research purposes by contacting IVIA (Apartado Oficial, 46113 Moncada, Valencia, Spain) after signing a nonpropagation agreement with IVIA and INIA.

\section{Literature Cited}

Ballester-Olmos, J.F., J.A. Pina, E.A. Carbonell, P Moreno, A. Hermoso de Mendoza, M. Cambra, and L. Navarro. 1993. Biological diversity of citrus tristeza virus (CTV) isolates in Spain. Plant Pathol. 42:219-229.

Fig. 3. Fruits and seeds of Forner-Alcaide 13 (F-A 13).

Field evaluations showed that F-A 5 is more tolerant to lime-induced chlorosis than Carrizo citrange, although F-A 13 is less tolerant (Forner et al., 1997).

Both selections have good tolerance to salinity. In trials carried out with seedlings and grafted plants (unpublished data), $\mathrm{Cl}^{-} \mathrm{ab}-$ sorption is similar to Cleopatra mandarin, but $\mathrm{Na}^{+}$absorption is lower.

Both also have an excellent tolerance to flooding. A hard flooding originating from the river Jucar affected an experimental plot of 'Navelina' orange grafted on more than 90 rootstocks, 3-years-old. An evaluation of the tolerance to flooding of the rootstocks (unpublished data) showed that most trees $(>70 \%)$ on F-A 5, F-A 13, Carrizo citrange, and Swingle citrumelo rootstocks survived, while most trees $(>80 \%)$ on Troyer citrange or Cleopatra mandarin rootstocks died.

F-A 5 is resistant to the citrus nematode Tylenchulus semipenetrans Cobb, while F-A 13 is susceptible (Verdejo-Lucas et al., 1997, 2000).
F-A 5 appears to have good field resistance to Phytophthora sp. in Spain. Although specific inoculations have not been performed, no symptoms of damage from these fungi, either in the greenhouse or in the field, have been observed (even under favorable conditions for the attack of Phytophthora). Similarly, no trees of orange varieties on F-A 13 rootstock with Phytophthora symptoms have been detected in the field, although trees with Clementine scions have been more susceptible.

Both hybrids performed well in the nursery. Seedlings are very uniform ( $<1 \%$ off-types), with few rootsprouts, although varieties grafted on them grow slower than on Carrizo citrange.

In an experimental plot of 10-year-old 'Navelina' orange planted in a sandy-loam soil, with $24.6 \%$ of $\mathrm{CaCO}_{3}$, and $\mathrm{pH}=7.5$ (Forner-Giner et al., 2003), trees on F-A 5 or F-A 13 rootstocks yielded $\approx 40 \%$ more than trees on Carrizo citrange rootstock, but with similar fruit quality. On both selec-
Forner, J.B. and A. Alcaide. 1993. La mejora genética de patrones de agrios tolerantes a tristeza en España: 20 años de historia (I). Levante Agrícola 325:261-267.

Forner, J.B. and A. Alcaide. 1994. La mejora genética de patrones de agrios tolerantes a tristeza en España: 20 años de historia (II). Levante Agrícola 329:273-279.

Forner, J.B., A. Alcaide, S. Verdejo-Lucas, and F.J. Sorribas. 1997. New hybrids as citrus rootstocks in Spain, p. 167-170. In: B. Manicom, J. Robinson, S.F. du Plessis, P. Joubert, J.L. van Zyl, and S. du Preez (eds.). Proc. 8th Intl. Citrus Congr. Vol. I. Sun City, South Africa.

Forner-Giner,M.A.,A.Alcaide, E. Primo-Millo, and J.B. Forner. 2003. Performance of 'Navelina' orange on 14 rootstocks in northern Valencia (Spain). Scientia Hort. 98:223-232.

Verdejo-Lucas, S., F.J. Sorribas, J.B. Forner, and A Alcaide. 1997. Screening hybrid citrus rootstocks for resistance to Tylenchulus semipenetrans Cobb. HortScience 32:1116-1119.

Verdejo-Lucas, S., F.J. Sorribas, J.B. Forner, and A. Alcaide. 2000. Resistance of hybrid citrus rootstocks to a mediterranean biotype of $T y$ lenchulus semipenetrans Cobb. HortScience 35(2):269-273. 